$$
\text { CONF-951155--113 }
$$

\title{
Chemical Evolution of Cementitious Materials with High Proportion of Fly Ash and Slag
}

Prepared for the U.S. Department of Energy Assistant Secretary for Environmental Management

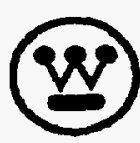
Hanford Company Richland, Washington

Management and Operations Contractor for the

U.S. Department of Energy under Contract DE-AC06-87RL10930

Copyright License By acceptance of this article, the publisher and/or recipient acknowledges the

U.S. Government's right to retain a nonexclusive, royalty-free license in and to any copyright covering this paper.

Approved for public release

DISTRBUTION OF THIS DOCUMEAT IS UNMTIEO

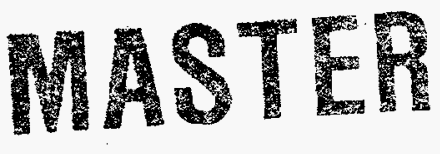




\begin{tabular}{|c|c|c|c|c|c|}
\hline \multicolumn{6}{|c|}{ DISTRIBUTION SHEET } \\
\hline \multirow{2}{*}{$\begin{array}{l}\text { To } \\
\text { Distribution }\end{array}$} & \multirow{2}{*}{\multicolumn{2}{|c|}{$\begin{array}{l}\text { From } \\
\text { Albert A. Kruger }\end{array}$}} & & \multicolumn{2}{|l|}{ Page 1 of 1} \\
\hline & & & & \multicolumn{2}{|c|}{\begin{tabular}{|ll} 
Date 6 March 1996 \\
\end{tabular}} \\
\hline Project Title/Work Order & & & & \multicolumn{2}{|l|}{ EDT No. N/A } \\
\hline \multicolumn{4}{|c|}{$\begin{array}{l}\text { Chemical Evolution of Cementitious Materials with High } \\
\text { Proportion of Fly Ash and Slag, WHC-SA-3022-FP }\end{array}$} & \multicolumn{2}{|c|}{ ECN No. $N / A$} \\
\hline Name & MSIN & $\begin{array}{c}\text { Text } \\
\text { With All } \\
\text { Attach. }\end{array}$ & Text Only & $\begin{array}{l}\text { Attach./ } \\
\text { Appendix } \\
\text { Only }\end{array}$ & $\begin{array}{l}\text { EDT/ECN } \\
\text { Only }\end{array}$ \\
\hline $\begin{array}{l}\text { Central Files } \\
\text { N. R. Brown } \\
\text { K. C. Burgard } \\
\text { R. Carreon } \\
\text { S. J. Eberlein } \\
\text { R. L. Gibby } \\
\text { J. W. Hunt } \\
\text { L. A. Huffman } \\
\text { J. G. Kristofzski } \\
\text { A. A. Kruger } \\
\text { J. W. Shade } \\
\text { J. A. Voogd } \\
\text { OSTI (2) }\end{array}$ & $\begin{array}{l}\text { A3-88 } \\
\text { S7-53 } \\
H 5-03 \\
S 7-53 \\
\text { R2-12 } \\
\text { H5-03 } \\
\text { R2-12 } \\
\text { S7-53 } \\
\text { R2-12 } \\
\text { R2-12 } \\
\text { H5-27 } \\
\text { H5-03 } \\
\text { G3-11 }\end{array}$ & $\begin{array}{l}x \\
X \\
X \\
x\end{array}$ & & & \\
\hline
\end{tabular}


LEGAL DISCLAIMER

This report was prepared as an account of work sponsored by an agency of the United States Government. Neither the United States Government nor any agency thereof, nor any of their employees, nor any of their contractors, subcontractors or their employees, makes any warranty, express or implied, or assumes any legal liability or responsibility for the accuracy, completeness, or any third party's use or the results of such use of any information, apparatus, product, or process disclosed, or represents that its use would not infringe privately owned rights. Reference herein to any specific commercial product, process, or service by trade name, trademark, manufacturer, or otherwise, does not necessarily constitute or imply its endorsement, recommendation, or favoring by the United States Government or any agency thereof or its contractors or subcontractors. The views and opinions of authors expressed herein do not necessarily state or reflect those of the United States Government or any agency thereof.

This report has been reproduced from the best available copy.

Printed in the United States of America

DISCLM-2.CHP (1-91) 


\title{
Chemical Evolution of Cementitious Materials with High Proportion of Fly Ash and Slag
}

\author{
A. A. Kruger \\ Date Published \\ December 1995
}

Presented at

1995 Fall Meeting of the Materials Research Society

Boston, Massachuetts

November 27-December 1, 1995

To Be Published in

Proceedings

Prepared for the U.S. Department of Energy

Assistant Secretary for Environmental Management

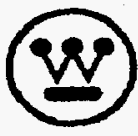

$$
\begin{array}{ll}
\text { Westinghouse } & \text { P.O Box } 1970 \\
\text { Hanford Company } & \text { Richland, Washington }
\end{array}
$$

Management and Operations Contractor for the

U.S. Department of Energy under Contract DE-AC06-87RL10930

Copyright License By acceptance of this article, the publisher and/or recipient acknowledges the

U.S. Government's right to retain a nonexclusive, royalty-free license in and to any copyright covering this paper. 


\title{
CHEMICAL EVOLUTION OF CEMENTITIOUS MATERIALS WITH HIGH PROPORTION OF FLY ASH AND SLAG
}

Evolution of alkali activated cementitious materials

T. BAKHAREV, A.R. BROUGH, R.J. KIRKPATRICK,

L.J. STRUBLE, and J.F. YOUNG

University of Illinois, Urbana, II.

\begin{abstract}
Cement mixtures containing high proportions of slag and fly ash were tested to assess their suitability to immobilize simulated off-gas waste solutions after vitrification of low-level radioactive tank wastes stored at Hanford. Materials were mixed with carbonated or alkaline solutions and cured initially adiabatically, then at $70^{\circ} \mathrm{C}$. Chemical changes were monitored for 7 months using $\mathrm{X}$-ray diffraction, selective dissolution and SEM; NMR was utilized to follow the polymerization of silicate species. The process of hydration during the first months of curing was characterized by formation of quite crystalline Al-substituted $\mathrm{C}-\mathrm{S}-\mathrm{H}$ structurally related to $1.1 \mathrm{~nm}$ tobermorite and traces of zeolites in some materials. A low content of calcium hydroxide was found in all materials after 1 month of curing. The SEM examination demonstrated rapidly decreasing porosity, making the mixtures favorable for long-term durability.

Keywords: hydration, chemistry, cement, fly ash, slag, wasteforms.
\end{abstract}

\section{Introduction}

To predict the performance of cementitious waste forms in different environments, it is necessary to consider the development of phase composition and microstructure due to hydration reactions. The main product of hydration, calcium silicate hydrate $(\mathrm{C}-\mathrm{S}-\mathrm{H})$, is the matrix-forming phase in cementitious systems. Its properties determine to a large extent the properties of the matrix itself (permeability, diffusivity, and thermodynamic stability). The research presented here is part of a study of the chemistry, microstructure and durability of cement-stabilized low level radioactive wastes. A companion paper on durability is included in this symposium [1].

Several factors make these wasteforms quite different from ordinary portland cement paste hydrated at room temperature. The liquid phase contains appreciable alkali and hydroxide ions. These provide early activation of slag and fly ash. Such activation 


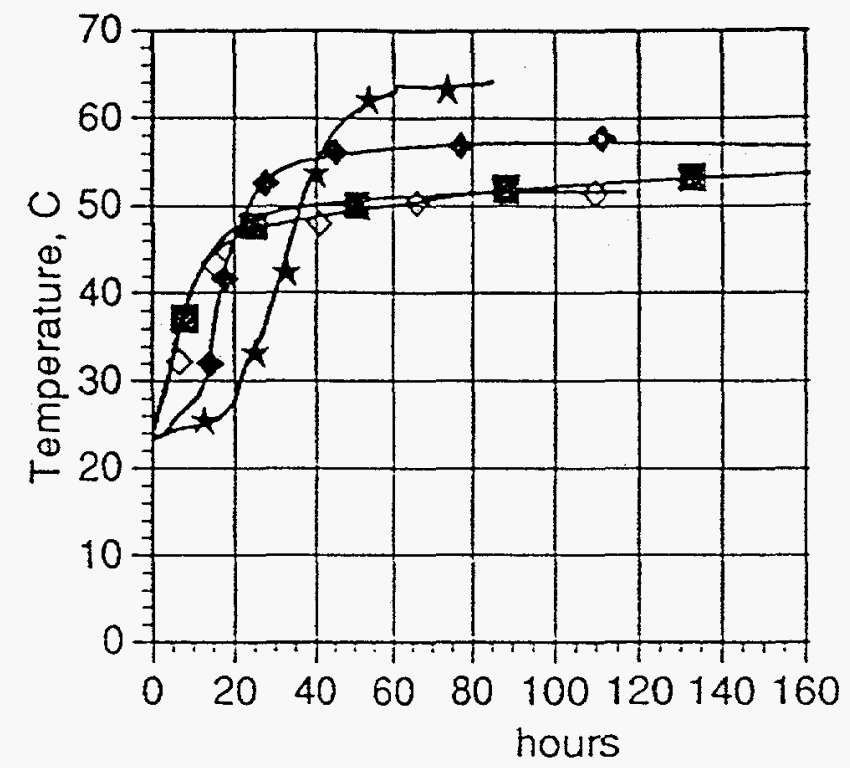

$3: 3: 3: 1 \mathrm{C}$

3:0:6:1C

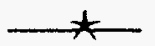

$3: 5: 1: 1 \mathrm{~A}$

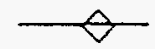

$3: 4: 2: 1 \mathrm{~A}$

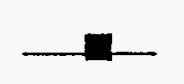

Figure 1. Adiabatic calorimetry.

served. The method is not suitable for quantitative determination of unreacted cement phases. The calculations were based on ignited weight. The procedure utilized can be found in $[2,3]$.

Specimens for ${ }^{29} \mathrm{Si}$ MAS NMR spectroscopy were ground to a powder and packed into zirconia rotors. The single-pulse ${ }^{29}$ Si MAS NMR spectra were acquired using a GE WD-300 spectrometer equipped with an Oxford Instruments superconducting magnet (magnetic field $7 \mathrm{~T}$ and operating frequency of $59.62 \mathrm{MHz}$ for ${ }^{29} \mathrm{Si}$ ). The ${ }^{29} \mathrm{Si}$ chemical shifts are given relative to tetramethylsilane (TMS) at $0 \mathrm{ppm}$.

\section{Results}

\subsection{XRD}

Powder XRD spectra for hydrated materials are shown in Figures 2-3. The main hydration products at 1 month were $\mathrm{C}-\mathrm{S}-\mathrm{H}(\mathrm{I})$, hydrotalcite, AFm (which appears to be hemicarboaluminate), and calcite; trace amounts of calcium hydroxide, a sodalite and $\mathrm{Na}-\mathrm{P} 1$ were present in some of the mixtures. The rate of pozzolanic reaction was observed to be different for the two solutions. The maximum intensity for the calcium hydroxide peaks for the carbonated solution was observed at 3 days, while for the alkaline solution it was observed at 7 days. At 28 days only trace amounts of calcium hydroxide were present in all materials. Traces of a sodalite were observed in 3:4:2:1 A and 3:5:1:1 A at early ages (3-5 days). Later traces of $\mathrm{Na}-\mathrm{X}$ and $\mathrm{Na}-\mathrm{Pl}$ zeolite (gismondine) were also observed (Figures 2-3). Crystallization of zeolites in the matrix of materials 3:4:2:1A and 3:5:1:1 A did not cause loss of strength [1]. In most samples, the C-S-H appeared to be largely amorphous. More crystalline $\mathrm{C}-\mathrm{S}-\mathrm{H}$, structurally related to $1.1 \mathrm{~nm}$ tobermorite, was observed in 3:4:2:1 A and in 3:3:3:1C after 2 months (Figure 3).

\subsection{SEM}

The examination of fracture surfaces of 3:3:3:1C and 3:0:6:1C at 1 month showed a considerable amount of the AFm and hydrotalcite-type phases. The back scattered electron 
Table 1. Composition of solutions

\begin{tabular}{|c|c|c|c|c|c|c|c|}
\hline & $\begin{array}{l}\mathrm{A} \\
\mathrm{g} / \mathrm{l}\end{array}$ & $\begin{array}{l}\mathrm{C}, \\
\mathrm{g} / 1\end{array}$ & $\begin{array}{l}\text { Oxide } \\
\mathrm{SiO}_{2}\end{array}$ & $\begin{array}{c}\text { Cement } \\
22.17\end{array}$ & $\begin{array}{l}\text { Fly ash } \\
46.13\end{array}$ & $\begin{array}{l}\operatorname{Slag}^{3} \\
37.0\end{array}$ & $\begin{array}{l}\text { Clay }^{4} \\
59.71\end{array}$ \\
\hline $\mathrm{Al}\left(\mathrm{NO}_{3}\right)_{3} \cdot 9 \mathrm{H}_{2} \mathrm{O}$ & 7.03 & 7.03 & $\mathrm{Al}_{2} \mathrm{O}_{3}$ & 3.24 & 25.02 & 8.0 & 9.05 \\
\hline \multirow{2}{*}{$\mathrm{Na}_{3}\left(\mathrm{PO}_{4}\right) \cdot 12 \mathrm{H}_{2} \mathrm{O}$} & \multirow{2}{*}{24.53} & \multirow{2}{*}{24.53} & $\mathrm{Fe}_{2} \mathrm{O}_{3}$ & 4.24 & 7.25 & 0.2 & 3.17 \\
\hline & & & $\mathrm{CaO}$ & 64.48 & 8.02 & 39.0 & 3.13 \\
\hline $\mathrm{NaNO}_{2}$ & 12.17 & 12.17 & $\mathrm{MgO}$ & 1.13 & 1.81 & 11.0 & 11.2 \\
\hline \multirow{2}{*}{$\mathrm{NaOH}$} & \multirow[t]{2}{*}{53.76} & \multirow[t]{2}{*}{-} & $\mathrm{K}_{2} \mathrm{O}$ & 0.52 & 0.63 & 0.4 & 0.83 \\
\hline & & & $\mathrm{Na}_{2} \mathrm{O}$ & 0.15 & 4.74 & 0.3 & 0.07 \\
\hline $\mathrm{NaNO}_{3}$ & 32.73 & 32.73 & $\mathrm{TiO}_{2}$ & 0.23 & 4.70 & 0.4 & 0.42 \\
\hline \multirow{4}{*}{$\mathrm{Na}_{2} \mathrm{CO}_{3}$} & \multirow[t]{4}{*}{-} & \multirow[t]{4}{*}{39.97} & $\mathrm{P}_{2} \mathrm{O}_{5}$ & 0.12 & 0.42 & 0.01 & 1.47 \\
\hline & & & $\mathrm{MnO}$ & 0.06 & 0.03 & 0.5 & 0.05 \\
\hline & & & $\mathrm{SO}_{3}$ & 2.14 & 0.12 & 2.8 & $<0.1$ \\
\hline & & & $\begin{array}{l}\text { Loss on } \\
\text { ignition }\end{array}$ & 1.20 & 0.53 & 0.39 & 10.64 \\
\hline
\end{tabular}

1 Type U/II, Ash Grove, Durkee, OR

2 Type F, Centralia, Ross Sand and Gravel Co., Portland, OR

3 Koch Minerals Co., Chicago, IL

4 Attapulgite, Engelhard Co., Iselin, NJ

plus adiabatic curing conditions produce quite high reaction temperatures. These factors cause considerable changes in hydration chemistry.

\section{Experimental}

The solid materials (cement, fly ash, slag and clay) were mixed at room temperature with either alkaline (A) or carbonated (C) solution. Solids were mixed with liquid at $w / s$ ratio of 1 ( 1 liter of liquid mixed with $1 \mathrm{~kg}$ of solid). The compositions of solutions are shown in Table 1. The mixtures tested are designated by their proportion (by weight) of cement, fly ash , slag and clay. For example, the material $3: 3: 3: 1$ contains $30 \%$ cement, $30 \%$ fly ash, $30 \%$ slag and $10 \%$ clay. The oxide compositions of the cement, fly ash, slag and attapulgite clay are shown in Table 2.

The materials were sealed in tubes and cured adiabatically for the first 4 days, after which they were cured isothermally at $70^{\circ} \mathrm{C}$ for 7 months. Adiabatic calorimetry results are shown in Figure 1. At the desired age hydration was stopped by crushing the pastes and immersing in methanol for 7 days. The samples were then dried in vacuo and kept under vacuum until analyzed.

The weight percent of slag and fly ash reacted at different ages was determined by selective dissolution of materials in salicylic acid and methanol. In this method C$S-H$ and cement are largely dissolved, while $\sim 97 \%$ of fly ash and $\sim 85 \%$ slag are pre- 


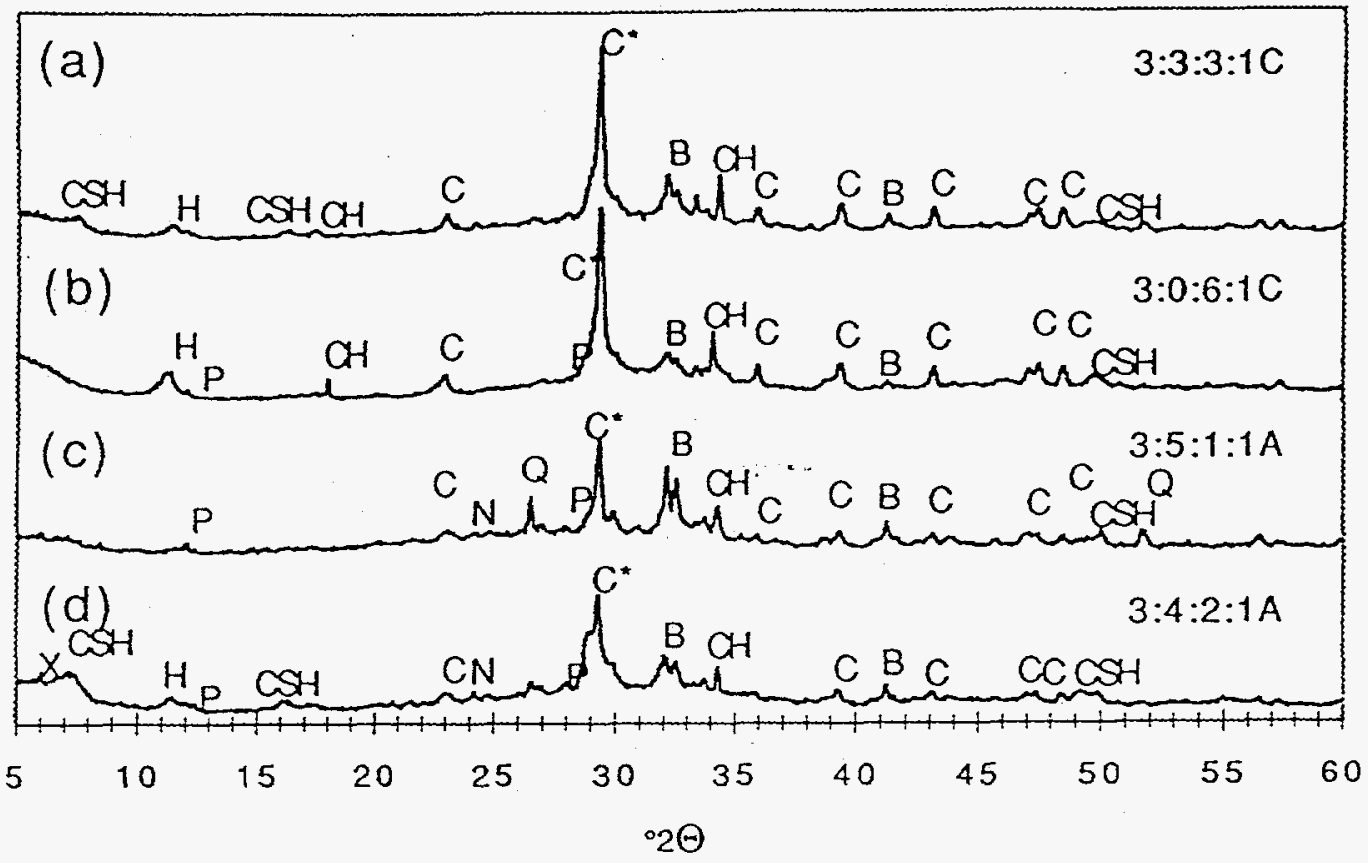

Figure 2. Powder XRD spectra of samples hydrated for one month, acquired with $\mathrm{Cu}$ $\mathrm{K} \alpha$ radiation; $\mathrm{B}=$ belite, $\mathrm{C}-\mathrm{S}-\mathrm{H}=$ calcium silicate hydrate, $\mathrm{C}=$ calcium carbonate (calcite), $C^{*}=$ overlapping $\mathrm{C}-\mathrm{S}-\mathrm{H}$ and calcite, $\mathrm{H}=$ hydrotalcite $\left(\left[\mathrm{Mg}_{6} \mathrm{Al}_{2}(\mathrm{OH})_{16}\right] \cdot \mathrm{CO}_{3} \cdot\right.$ $\left.4 \mathrm{H}_{2} \mathrm{O}\right)$ and $\mathrm{AFm}$-type phase, hemicarbonate $\left(\mathrm{C}_{4} \mathrm{AC}_{1 / 2} \mathrm{H}_{12}\right), \mathrm{N}=$ a sodalite type zeolite, $\mathrm{P}=\mathrm{Na}-\mathrm{P} 1$, zeolite (gismondine), $\mathrm{Q}=$ quartz, $\mathrm{X}=\mathrm{Na}-\mathrm{X}$ zeolite; (a) 3:3:3:1C, (b) 3:0:6:1C, (c) $3: 5: 1: 1 \mathrm{~A}$, (d) $3: 4: 2: 1 \mathrm{~A}$.

image (BEI) of these materials showed a reaction rim surrounding slag and fly ash particles, and in the space between them plate-like AFm and hydrotalcite were crystallized (Figure 4). There was much unreacted material and unfilled space between the particles. Examination at later ages showed that the course of reaction differed between the two solutions. In the alkaline solution (A), slag and fly ash were activated earlier and dissolved from the surface more rapidly than in the carbonated solution (C) (for example, see Figure 5 at 2 months). In the latter we observed precipitated $\mathrm{C}-\mathrm{S}-\mathrm{H}$ on the surface of particles (Figure 6). Dissolution of fly ash in the carbonated case occured only at 4 months, when the glassy phase of some of fly ash particles has dissolved leaving distorted shells of outer product $\mathrm{C}-\mathrm{S}-\mathrm{H}$, which had presumably formed earlier (see Figure 7). A lot of reaction seams to take place in the hardened matrix through dissolution and precipitation. As a result of the continuing hydration a finer porosity and more uniform matrix is observed at later ages in all the materials (for example, see Figure 8 at 7 months).

\subsection{Selective Dissolution}

Table 3 shows the weight percent of slag and fly ash reacted at different ages determined by selective dissolution. The results are consistent with other invetigations of blended cements $[2,3,7]$. The total amount of fly ash and slag was $\sim 60 \%$ in all mixtures. The results show that hydration continued throughout the time period.

\subsection{NMR}

Figure 9 shows the Si MAS NMR spectra for 3:3:3:1C and 3:0:6:1C at the ages of 1 month and 7 months. We observed considerable intensity of $\mathrm{Q}^{2}(\mathrm{IAl})$ at $\sim-82 \mathrm{ppm}$ and 


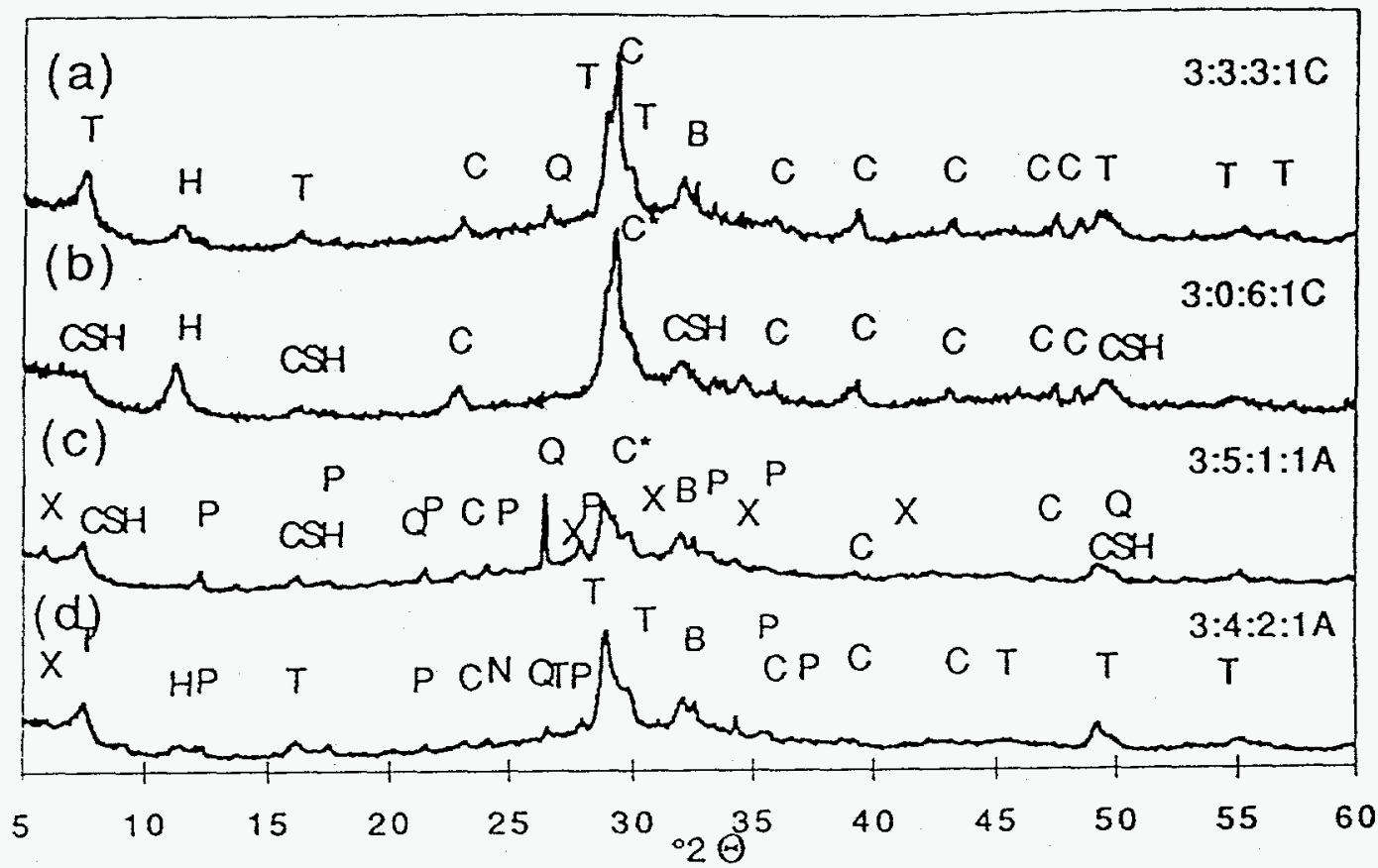

Figure 3. Powder XRD spectra of samples hydrated for seven months, acquired with $\mathrm{Cu} \mathrm{K} \alpha$ radiation; $\mathrm{B}=$ belite, $\mathrm{C}-\mathrm{S}-\mathrm{H}=$ calcium silicate hydrate, $\mathrm{C}=$ calcium carbonate (calcite), $\mathrm{C}^{*}=$ overlapping $\mathrm{C}-\mathrm{S}-\mathrm{H}$ and calcite, $\mathrm{H}=$ hydrotalcite $\left(\left[\mathrm{Mg}_{6} \mathrm{Al}_{2}(\mathrm{OH})_{16}\right] \cdot \mathrm{CO}_{3}\right.$ - $\left.4 \mathrm{H}_{2} \mathrm{O}\right)$ and $\mathrm{AFm}$-type phase, hemicarbonate $\left(\mathrm{C}_{4} \mathrm{AC}_{1 / 2} \mathrm{H}_{12}\right), \mathrm{N}=$ a sodalite type zeolite, $\mathrm{P}=\mathrm{Na}-\mathrm{P} 1$, zeolite (gismondine), $\mathrm{Q}=$ quartz, $\mathrm{T}=$ more crystalline $\mathrm{C}-\mathrm{S}-\mathrm{H}, \mathrm{X}=\mathrm{Na}-\mathrm{X}$ zeolite; (a) $3: 3: 3: 1 \mathrm{C}$, (b) 3:0:6:1C, (c) $3: 5: 1: 1 \mathrm{~A}$, (d) $3: 4: 2: 1 \mathrm{~A}$.

$\mathrm{Q}^{2}(0 \mathrm{Al})$ at $\sim-85.5 \mathrm{ppm}$ for all the samples. The results are in agreement with observations of other authors for ordinary Portland cement [4], alite [5] and slag hydration [6].

\section{Discussion}

As expected, the course of reaction was different in the carbonate and alkaline solutions. Larger amounts of portlandite were observed in the alkaline solution and were consumed later. The amounts of AFm and hydrotalcite were found to relate to the amount of slag, because slag is activated more rapidly than fly ash and releases Al and $\mathrm{Mg}$. In 3:4:2:1 A and 3:5:1:1 A some $\mathrm{Al}$ crystallized in sodalite, $\mathrm{Na}-\mathrm{Pl}$ and $\mathrm{Na}-\mathrm{X}$ zeolites instead of $\mathrm{AFm}$ due to

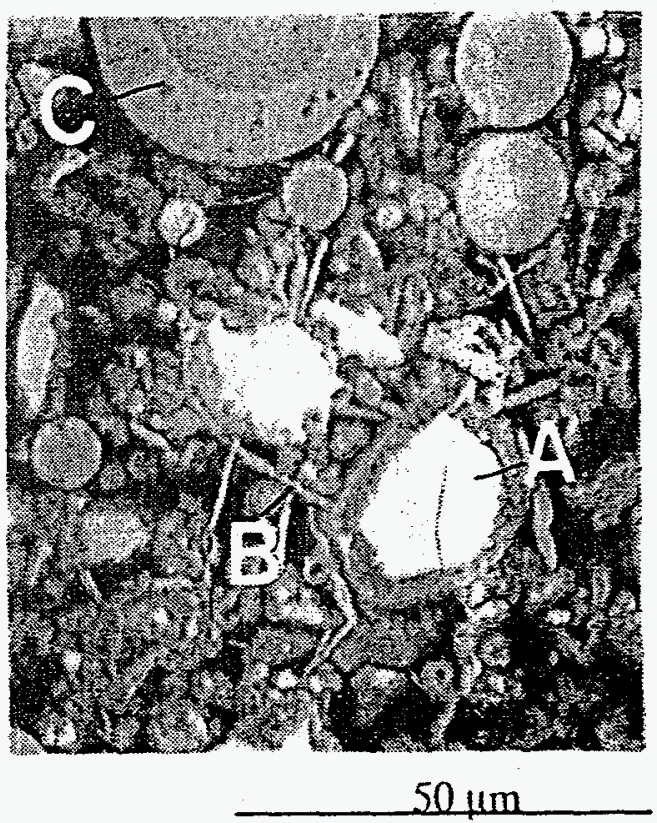

Figure 4. BEI of $3: 3: 3: 1 \mathrm{C}$ at 1 month; A-slag, B-hydrotalcite and AFm phases, C-fly ash particle. 


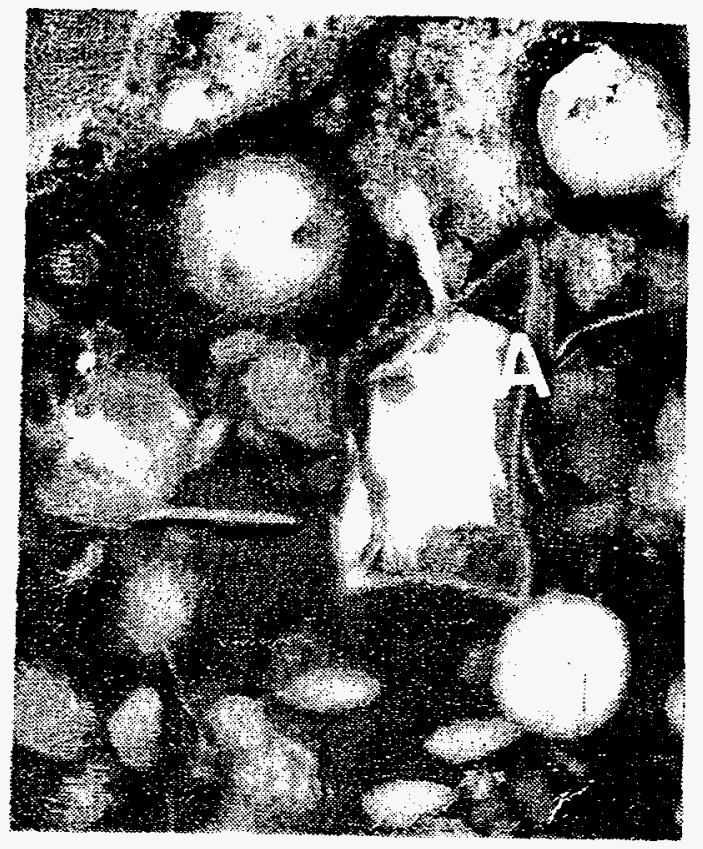

$20 \mu \mathrm{m}$

Figure 5. BEI 3:5:1:1A at 2 months; A-activated slag particle.

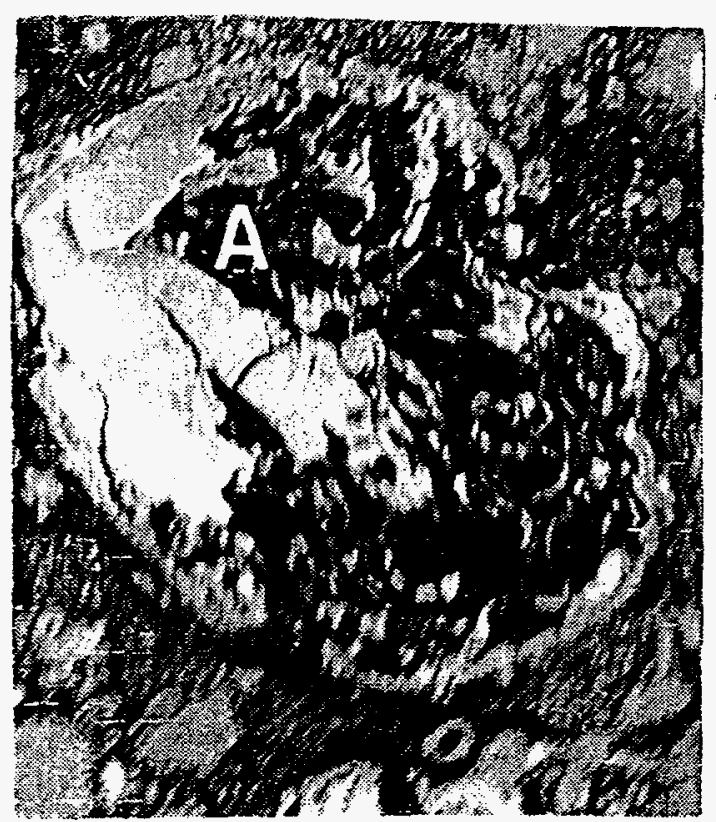

$50 \mu \mathrm{m}$

Figure 7. BEI 3:3:3:1C at 4 months; A-activated fly ash sphere.

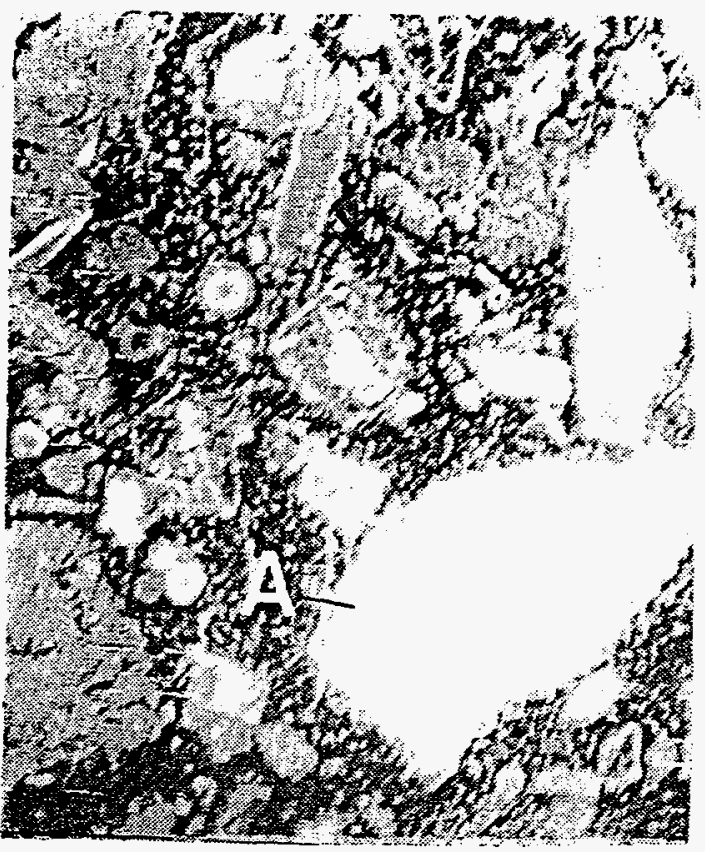

$25 \mu \mathrm{m}$

Figure 6 . BEI $3: 3: 3: 1 \mathrm{C}$ at 4 months; A-slag particle.

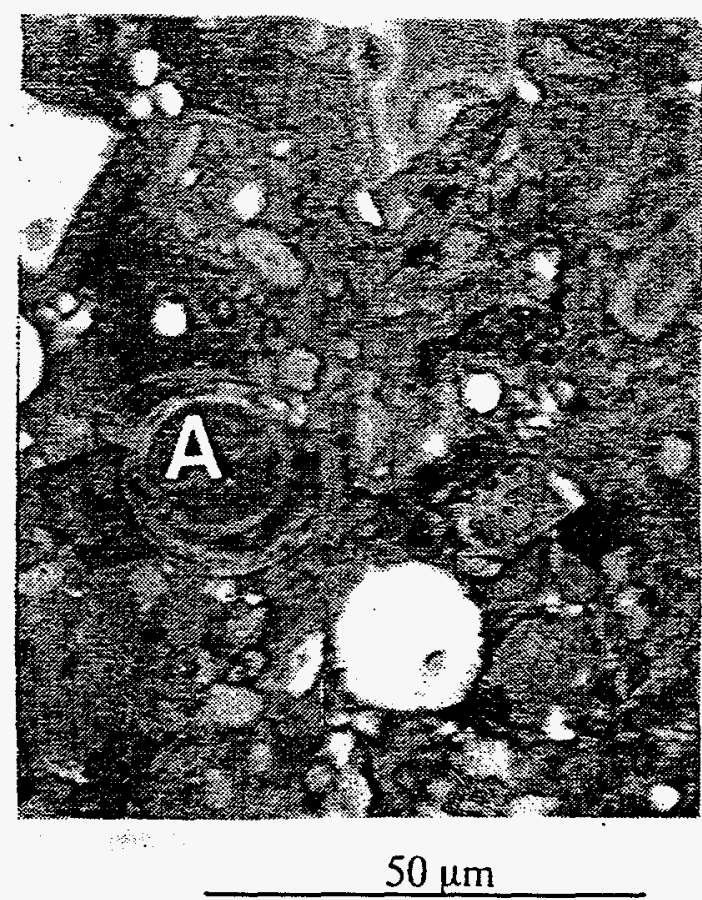

Figure 8. BEI of $3: 3: 3: 1 \mathrm{C}$ at 7 months; A-fully reacted fly ash sphere. 


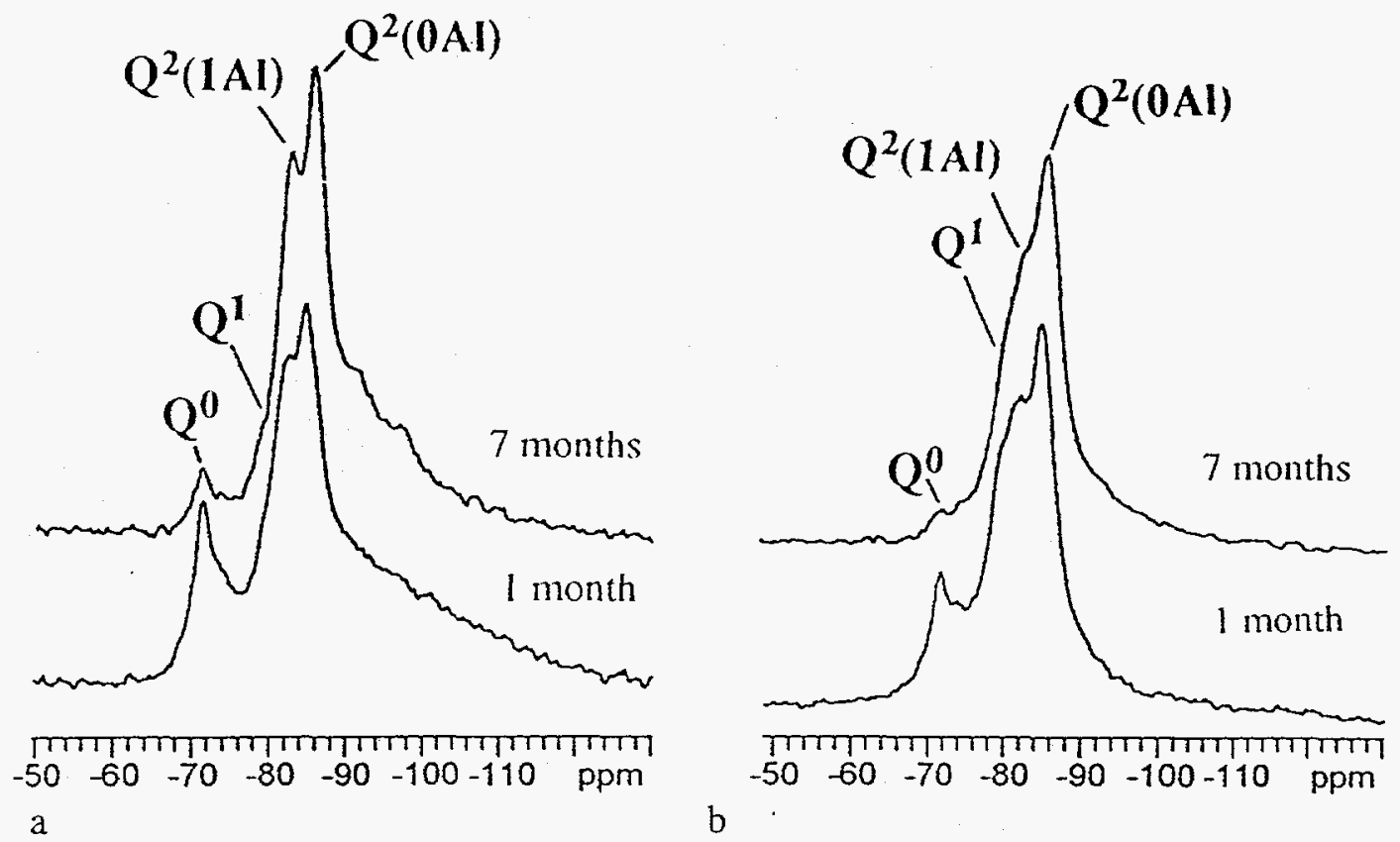

Figure 9. ${ }^{29}$ Si MAS NMR spectra for waste materials (a) 3:3:3:1C, (b) 3:0:6:1C. The single pulse spectra were acquired ( 4000 scans) using a pulse recycle delay of $10 \mathrm{~s}$ and a flip angle of $90^{\circ}$.

the low $\mathrm{C} / \mathrm{S}$ ratio of solids and the presence of considerable alkali. At early ages we observed traces of a sodalite, and later a combination of sodalite, $\mathrm{Na}-\mathrm{Pl}$ and $\mathrm{Na}-\mathrm{X}$ zeolites, although $\mathrm{Na}-\mathrm{Pl}$ was prevailing.

By NMR high intensity of $\mathrm{Q}^{2}(\mathrm{Al})$ at $\sim-82 \mathrm{ppm}$ was observed for all materials from the early stage of hydration, showing that the precipitated $\mathrm{C}-\mathrm{S}-\mathrm{H}$ had a considerable substitution of Al. For all the samples at 7 months we observed a high intensity of $\mathrm{Q}^{2}(1 \mathrm{Al})$ and $\mathrm{Q}^{2}(0 \mathrm{Al})$, and very little intensity for $\mathrm{Q}^{1}$ at $-79.9 \mathrm{ppm}$ (chain terminating groups), which indicates the formation of C-S-H with quite long chains. The 3:0:6:1C spectrum had the highest intensity of $\mathrm{Q}^{1}(\sim-79.9 \mathrm{ppm})$, so the average chain length in 3:0:6:1C was the lowest.

Table 3 . Weight percent of slag and fly ash reacted determined by selective dissolution

\begin{tabular}{lcccc|}
\hline Age & $3: 3: 3: 1 \mathrm{C}$ & $3: 0: 6: 1 \mathrm{C}$ & $3: 5: 1: 1 \mathrm{~A}$ & $3: 4: 2: 1 \mathrm{~A}$ \\
10 days & 29 & 49 & 24 & 42 \\
1 month & 42 & 62 & 36 & 55 \\
5 month & nd* & nd & 42 & 65 \\
7 month & 54 & 75 & nd & nd \\
\hline
\end{tabular}

* not determined 


\section{Conclusions}

The reactions observed in alkali activated cementitious materials cured at elevated temperatures resulted in the formation of Al-substituted $\mathrm{C}-\mathrm{S}-\mathrm{H}$ structurally related to 1.1 $\mathrm{nm}$ tobermorite, and traces of sodalite, $\mathrm{Na}-\mathrm{Pl}$, and $\mathrm{Na}-\mathrm{X}$ zeolites. The $\mathrm{Na}-\mathrm{Pl}$ zeolite was found to replace a sodalite at later ages. A considerable substitution of $\mathrm{Al}$ in $\mathrm{C}-\mathrm{S}-\mathrm{H}$ was observed from a very early age. In some samples considerable crystallinity was found in $\mathrm{C}-\mathrm{S}-\mathrm{H}$ at 7 months. These reactions can be explained by the low $\mathrm{C} / \mathrm{S}$ ratio of the mix and the large amount of AI that was activated by alkaline solution. The rates of fly ash and slag activation were found to depend on the initial pH and composition of the solution. The system is moving to a more stable phase assemblage that is characterized by crystallization of $\mathrm{Al}$ substituted $\mathrm{C}-\mathrm{S}-\mathrm{H}$ that has quite long chain lengths and is more crystalline and structurally related to $1.1 \mathrm{~nm}$ tobermorite. From SEM and dissolution work it is evident that the degree of reaction is increasing with time, creating more fine microporosity and filling the larger pores. As the microstructure becomes more uniform, its permeability is decreasing, improving the resistance of these materials to deterioration.

\section{Acknowledgement}

The research was funded by grant MTS-SVV-097600 from the Westinghouse Hanford Company. We thank the Ross Sand and Gravel Co., Koch Mineral Co., Engelhard Co., and the Ash Grove Cement Co. for materials.

\section{References}

1. Bakharev, T., Brough, A.R., Kirkpatrick, R. J., Struble,L. J. and Young, J. F. (1996) Durability of cement stabilized low level wastes, in Mechanisms of Chemical Degradation of Cement-Based Systems, (ed. K.L. Scrivener and J.F. Young), E \& FN Spon, London, current volume.

2. Ohsawa, S., Asaga, K., Goto, S., and Daimon, M. (1985) Quantitative determination of fly ash in the hydrated fly ash- $\mathrm{CaSO}_{4} \cdot 2 \mathrm{H}_{2} \mathrm{O}-\mathrm{Ca}(\mathrm{OH})_{2}$ system. Cem. Concr. Res., Vol. 15, pp. 357-66.

3. Luke, K. and Glasser, F.P. (1987) Selective dissolution of hydrated blast furnace slag cements. Cem. Concr. Res., Vol. 17, pp. 273-82.

4. Barnes, J.R., Clague, A.D.H., Clayden, N.J., Dobson, C.M., Hayes, C.J., Groves, G.W. and Rodger, S.A. (1985) Hydration of Portland cement followed by ${ }^{29} \mathrm{Si}$ solid-state NMR spectroscopy. Joumal of Material Science Letter, Vol. 4, p. $1293-95$.

5. Young, J.F. (1988) Investigation of calcium silicate hydrate structure using silicon-29 nuclear magnetic resonance spectroscopy. J. Am. Ceram. Soc., Vol. 71, No. 3. pp. $\mathrm{C}-118-\mathrm{C}-120$.

6. Richardson, I.G., Brough, A.R., Groves G.W., and Dobson, C.M. (1994) The characterization of hardened alkali-activated blast-furnace slag pastes and the nature of the calcium silicate hydrate phase. Cem. Concr. Res., Vol. 24, pp. 813-29.

7. Luke, K. and Glasser, F.P. (1988) Internal chemical evolution of the constitution of blended cements Cem. Concr. Res., Vol. 18, pp. 495-502. 